\title{
SIKAP KEWIRAUSAHAAN DAN PENGARUHNYA TERHADAP PERKEMBANGAN USAHA KERAJINAN BATIK DI TASIKMALAYA
}

\author{
Mira Nurfitriya \\ Economic Education Program, Faculty of Economics and Bussines, Indonesia \\ University of Education \\ miranurfitriya@ rocketmail.com
}

\begin{abstract}
The problem in this research is business development in the form of profit of batik entrepreneurs in batik center of Tasikmalaya city that fluctuated up and down in the last 5 months. This is due to the lack of positive mental attitudes of batik entrepreneurs in the form of entrepreneurial attitudes such as confidence, task-oriented attitude and outcome, risk taking attitude, leadership attitude, future-oriented attitude, and the attitude of originality (creativity and innovation) to improve its business development.

In this study, the object of research is the batik entrepreneurs in the center of batik handicrafts Tasikmalaya city. The sample in this research were 31 people taken with saturated sampling technique. The method used in this research is explanatory survey using questionnaire as data collecting tool and technique using simple linear regression, in data analysis using SPSS 11.5 for Windows program.

Based on the result of the research, it is found that partially variable of entrepreneurship attitude have positive and significant effect to business development. From the research results also obtained R2 value of $74.1 \%$ which shows that the influence of entrepreneurial attitude toward business development is equal to $74.1 \%$, meaning $74.1 \%$ change in the profit of batik entrepreneurs in the center of batik handicrafts Tasikmalaya city influenced by entrepreneurial attitude and the rest $25.9 \%$ influenced by other factors.
\end{abstract}

Keywords: Entrepreneurial Attitude, Business Development, Profit.

\section{History of Article:}

\section{Citation (Example):}

Nurfitriya, Mira (2018) Sikap Kewirausahaan dan Pengaruhnya Terhadap Perkembangan Usaha Batik di Tasikmalaya. [Entrepreneurship and its Effect On Business Development Of Batik Enterprises In Tasikmalaya]. Jurnal Pendidikan Ekonomi, 11(1), 1-08. 


\section{PENDAHULUAN}

Tujuan utama dari suatu perusahaan adalah maksimalisasi keuntungan atau biasa dikenal dengan istilah profit oriented. Setiap pengusaha mempunyai latar belakang yang berbeda, baik dari segi pendidikan, pengalaman, dan kemampuannya. Namun terdapat perbedaan karakteristik antara pengusahapengusaha mikro di perkotaan dengan di pedesaan, diantaranya perbedaan dalam latar belakang pendidikan,pengalaman usaha, dan orientasi pasar. Dengan adanya perbedaan-perbedaan karakteristik tersebut, masing- masing pengusaha mencapai tujuan utama usahanya dengan hasil yang berbeda pula. Berdasarkan data yang diperoleh dari studi pendahuluan kepada para pengusaha Batik Tasik diperoleh data rata-rata keuntungan pengusaha dari 5 (lima) bulan terakhir sebagai berikut.

Tabel 1. Rata-Rata Perkembangan Laba Pengusaha Kerajinan Batik Tasik Kota Tasikmalaya

\begin{tabular}{|l|lc|c|}
\multicolumn{1}{|c}{ Bulan } & & Laba Total (Rp) & Pertumbuhan \\
\hline September 2012 & Rp & 9.471 .567 & - \\
\hline Oktober 2012 & Rp & 9.391 .203 & $-1 \%$ \\
\hline Nopember 2012 & Rp & 8.739 .526 & -7 \\
\hline Desember 2012 & Rp & 9.902 .642 & $13 \%$ \\
\hline Januari 2012 & Rp & 16.716 .370 & $69 \%$ \\
\hline
\end{tabular}

Sumber: Lampiran 001 (L.001)

Berdasarkan tabel 1 di atas terlihat bahwa perolehan laba pada pengusaha kerajinan batik di Kota Tasikmalaya periode September 2012 - Januari 2013 mengalami fluktuasi. Pada bulan September diketahui jumlah laba pengusaha kerajinan batik di Kota Tasikmalaya sebesar Rp 9.471.567. Sedangkan pada bulan Oktober dan Nopember mengalami penurunan yaitu masing-masing Rp 9.391.203 dan $\mathrm{Rp}$ 8.739.526. Kemudian mengalami kenaikan yang cukup tinggi pada bulan Desember dan Januari yaitu masing-masing sebesar Rp 9.902.642 dan Rp 16.716.370, hal tersebut disebabkan oleh semakin banyaknya permintaan karena menjelang tahun baru banyak konsumen yang memesan batik untuk acara- acara tertentu.

Pada dasarnya para pengusaha selalu ingin meningkatkan keuntungannya dengan penjualan produknya sebanyak mungkin kepada konsumen. Hal ini sesuai dengan yang dikemukakan oleh Sukirno (2002: p. 188) bahwa "dalam teori ekonomi, berbagai jenis perusahaan dipandang sebagai unit-unit badan usaha yang mempunyai tujuan yang sama, yaitu mencapai keuntungan yang maksimum." Mereka akan melakukan kegiatan memproduksi sampai pada tingkat dimana keuntungan mereka mencapai jumlah yang maksimum.

Teori dinamis, Schumpeter mengemukakan bahwa untuk memperoleh keuntungan yang maksimal, pengusaha harus menjadi yang terdepan. Seorang pengusaha bisa mendapatkan laba yang besar apabila pengusaha tersebut bias menjadi yang terdepan diantara pesaingnya. Para pengusaha selalu mempunyai ide-ide yang begitu banyak untuk menjalankan usahanya, yaitu berupa ide kreatif dan inovatif. Kreatif dan inovatif ini sangat penting dalam keberhasilan usaha, karena dengan begitu mereka akan lebih unggul dari pesaingnya sehingga mereka akan mendapatkan keuntungan melebihi pesaingnya. Kreativitas merupakan kemampuan yang dimiliki oleh manusia untuk mengubah sesuatu yang sudah ada menjadi lebih menarik (Fadiati \& Dedi Purwana; 2011). 
Dengan kata lain, pengusaha harus mempunyai sikap mental yang positif, sikap mental positif yang dimiliki oleh wirausaha dalam mengelola dan menjalankan usahanya dengan suatu motif yang mendasarinya kemudian akan membentuk suatu perilaku yang mendorong wirausaha untuk mengembangkan usahanya menjadi wirausaha yang sukses dan berhasil sesuai dengan keinginannya.

Sebagaimana dijelaskan sebelumnya bahwa keberhasilan suatu usaha ditentukan oleh karakteristik sikap dan perilaku para wirausaha. Keberhasilan dan kegagalan wirausaha sangat dipengaruhi oleh berbagai faktor, baik eksternal maupun internal. Keberhasilan suatu usaha dipengaruhi oleh suatu tindakan yang positif dalam menjalankan usahanya, tindakan atau perilaku tersebut dipengaruhi oleh nilai-nilai kepribadian wirausaha seperti yang dikemukakan oleh Suryana (2006: p. 52), "yaitu nilai-nilai keberanian menghadapi risiko, sikap positif, optimis, berani, mandiri, mampu memimpin, dan mau belajar dari pengalaman."

Seringkali pengusaha-pengusaha kecil yang tidak bisa mengikuti industri ini kurang optimis dan tidak mempunyai sikap yang positif dengan usaha yang dijalaninya, hal tersebut disebabkan oleh munculnya pengusaha-pengusaha lain yang lebih menguasai pasar sehingga menggeser posisi pengusaha kecil tersebut.

Tujuan dari penelitian ini adalah 1) Untuk memperoleh gambaran tentang perkembangan usaha dan sikap kewirausahaan Kerajinan Batik Kota Tasikmalaya; 2) Untuk mengetahui pengaruh sikap kewirausahaan terhadap perkembangan usaha Pengusaha Kerajinan Batik Kota Tasikmalaya.

\section{METODE PENELITIAN}

Metode yang digunakan dalam penelitian ini yaitu survei eksplanatori dengan menggunakan angket sebagai alat pengumpul data dan teknik menggunakan regresi linier sederhana, dalam analisis data menggunakan bantuan program SPSS 11.5 for Windows. Dalam penelitian ini yang menjadi objek penelitian yaitu para pengusaha batik di sentra kerajinan batik kota Tasikmalaya. Sampel dalam penelitian ini sebanyak 31 orang diambil dengan teknik sampling jenuh.

\section{HASIL DAN PEMBAHASAN}

Sebelum data masing-masing variabel dimasukan ke dalam analisis regresi, terlebih dahulu data yang bersifat ordinal yaitu X (sikap kewirausahaan) diubah menjadi interval dengan menggunakan MSI (Methods of Succesive Interval), karena merupakan syarat untuk regresi.

Dalam hasil penelitian ini, setelah melakukan pengujian beberapa model penelitian, penulis mengambil model dengan jumlah sampel sebanyak 31 responden $(n=31)$.

Tabel 2

Coefficients $^{\mathrm{a}}$

\begin{tabular}{|c|c|c|c|c|c|c|}
\hline \multirow[t]{2}{*}{ Model } & & \multicolumn{2}{|c|}{ Unstandardized Coefficients } & $\begin{array}{l}\text { Standardized } \\
\text { Coefficients }\end{array}$ & \multirow{2}{*}{$\mathrm{t}$} & \multirow{2}{*}{ Sig. } \\
\hline & & B & Std. Error & Beta & & \\
\hline 1 & (Constant) & $-25237649,114$ & 3966004,007 & & $-6,363$ & 000 \\
\hline & SIKAP & 1234524,678 & 135436,173 & .861 & 9,115 & 000 \\
\hline
\end{tabular}

a Dependent Variable: LABA 
Dari hasil pengolahan data seperti terlihat pada Tabel 2 di atas, dapat disimpulkan bahwa model fungsi persamaan linear pada perkembangan usaha terkait laba pengusaha batik di sentra kerajinan batik kota Tasikmalaya adalah sebagai berikut:

$$
\begin{aligned}
& \mathrm{Y}^{\prime} \quad=\mathrm{a}+\mathrm{bX} \\
& \mathrm{Y}^{\prime}=-25237649,114+0,1234524 \mathrm{X} \mathrm{Se} \\
& =(3966004,007)(135436,173) \\
& \mathrm{t}_{\text {hitung }} \quad=(-6,363)(9,115)
\end{aligned}
$$

Dimana:

$\mathrm{Y}^{\prime}=$ Perkembangan Usaha (Laba)

$\mathrm{X}=$ Sikap Kewirausahaan

Dari persamaan regresi di atas dapat diketahui bahwa:

Konstanta persamaan regresi -25237649 , artinya ketika variabel bebas (X) tidak ada, maka pengusaha akan mengalami kerugian sebesar 25.237.649 satu satuan.

Variabel X (sikap kewirausahaan) berpengaruh positif terhadap perkembangan usaha dengan koefisien regresi sebesar 0, 1234524, artinya ketika mempunyai sikap kewirausahaan, maka laba usaha akan bertambah sebanyak 0 , 1234524 satu satuan atau $12,34 \%$.

\section{Koefisien Determinasi}

Tabel 3

Koefisien Determinasi

\begin{tabular}{|l|r|r|r|c|}
\hline Model & $\mathrm{R}$ & R Square & $\begin{array}{c}\text { Adjusted R } \\
\text { Square }\end{array}$ & $\begin{array}{c}\text { Std. Error of the } \\
\text { Estimate }\end{array}$ \\
\hline 1 &, $861(\mathrm{a})$ &, 741 &, 732 & 5890435,73516 \\
\hline
\end{tabular}

a Predictors: (Constant), SIKAP

b Dependent Variable: LABA

Dari hasil pengolahan data yang terdapat pada tabel 3 diatas, diperoleh nilai $R^{2}$ sebesar 0,74 . Nilai $R$ Square $\left(R^{2}\right)$ menunjukkan bahwa besarnya pengaruh variabel bebas (sikap kewirausahaan) terhadap variabel terikat (perkembangan usaha) adalah sebesar 0,741 atau sebesar $74,1 \%$. Artinya bahwa $74,1 \%$ perubahan laba pengusaha batik di sentra kerajinan batik kota Tasikmalaya dapat ditentukan atau dijelaskan oleh variabel sikap kewirausahaan, sedangkan sisanya 25,9\% dipengaruhi oleh faktor-faktor lain.

\section{Pengujian Secara Parsial (Uji t)}

Uji hipotesis secara parsial dengan menggunakan uji t dapat dilihat dalam tabel 4 berikut. 
Tabel 4

Uji Hipotesis Secara

Parsial (Uji t)

\begin{tabular}{ccccc}
\hline Variabel & thitung & ttabel & Keputusan & Kesimpulan \\
\hline $\begin{array}{c}\text { Sikap } \\
\text { Kewirausahaan } \\
(\mathbf{X})\end{array}$ & $9,115>$ & 2,05 & Ho ditolak & Signifikan \\
\hline
\end{tabular}

Sumber: Data Olahan SPSS 11.5

Dari Tabel di atas, hasil uji t dengan menggunakan program SPSS 11.5 for Windows untuk koefisien X (sikap kewirausahaan) diperoleh t hitung sebesar 9,115 sedangkan $\mathrm{t}$ tabel dengan $\mathrm{df}=\mathrm{n}-\mathrm{k}-1=29$ dengan derajat kepercayaan $95 \%$ diperoleh nilai 2,05 dan menunjukan bahwa thitung $>\mathrm{t}$ tabel atau 9,115>2,05 yang berarti Ha diterima dan Ho ditolak. Hasil pengujian tersebut dapat disimpulkan bahwa dengan tingkat kepercayaan sebesar 95\% terdapat pengaruh yang signifikan dari sikap kewirausahaan terhadap perkembangan usaha (laba) pengusaha batik di sentra kerajinan batik kota Tasikmalaya.

\section{Pengaruh Sikap Kewirausahaan Terhadap Perkembangan Usaha Pada Pengusaha Batik di Sentra Kerajinan Batik Kota Tasikmalaya}

Hasil analisis data penelitian dan pengujian hipotesis, menunjukkan bahwa sikap kewirausahaan berpengaruh positif dan signifikan terhadap perkembangan usaha pengusaha batik di sentra kerajinan batik kota Tasikmalaya yang diukur menggunakan indikator laba. Dari hasil pengujian hipotesis diperoleh nilai $\mathrm{R}^{2}$ sebesar 0,74. Nilai $R$ Square $\left(\mathrm{R}^{2}\right)$ menunjukkan bahwa besarnya pengaruh variabel sikap kewirausahaan terhadap variabel perkembangan usaha adalah sebesar 0,741 atau sebesar $74,1 \%$. Artinya bahwa $74,1 \%$ perubahan laba pengusaha batik di sentra kerajinan batik kota Tasikmalaya dapat ditentukan atau dijelaskan oleh variabel sikap kewirausahaan, sedangkan sisanya 25,9\% dipengaruhi oleh faktorfaktor lain. Hal tersebut juga berarti semakin tinggi sikap kewirausahaan yang dimiliki oleh pengusaha maka dapat meningkatkan laba yang diperoleh pengusaha tersebut sehingga perkembangan usahanya juga meningkat.

Gambaran mengenai perkembangan usaha terkait laba pengusaha batik di sentra kerajinan batik kota Tasikmalaya sebagian besar masih tergolong memperoleh laba yang rendah yaitu sebanyak 24 orang (77\%) dari 31 pengusaha. Laba yang diperoleh pengusaha dari hasil produksi akan digunakan untuk mengembangkan perusahaan, yaitu dengan menginvestasikan kembali laba tersebut dalam bentuk pabrik dan peralatan baru, digunakan untuk membeli perusahaan lain, atau digunakan sebagai investasi keuangan oleh perusahaan.

Gambaran umum sikap kewirausahaan yang dimiliki para pengusaha batik di sentra kerajinan batik kota Tasikmalaya masih tergolong rendah, hal tersebut terlihat dari jawaban responden dan perhitungan terkait indikator-indikator sikap kewirausahaan yang masih tergolong ke dalam kategori rendah. Rendahnya sikap kewirausahaan yang dimiliki pengusaha batik disebabkan karena mereka tidak 
mendapatkan pendidikan dan pengetahuan yang cukup mengenai cara berwirausaha yang baik.

Untuk meningkatkan sikap kewirausahaan para pengusaha batik, diperlukan meningkatan pendidikan para pengusaha untuk meningkatkan mutu para pengusaha tersebut, khususnya pendidikan dalam bidang kewirausahaan agar para pengusaha mempunyai keterampilan, pengetahuan, dan kemampuan untuk mengembangkan usahanya yang didasari oleh sikap mental positif pengusaha tersebut.

Sikap kewirausahaan secara definisinya berarti kecenderungan berfikir (kognitif), merasa (afektif), dan berperilaku (konatif) dari seorang wirausaha dalam bekerja yang mengarah kepada upaya mencari, menciptakan, menerapkan cara kerja, teknologi dan produk baru, meningkatkan efisiensi, dan memperoleh keuntungan yang lebih besar. Sikap seseorang membawa pengaruh kepada perilaku atau tindakan yang akan diperbuatnya. Hal tersebut tercermin dalam motivasi yang timbul dari dalam diri wirausaha tersebut yang mendorong untuk terus maju.

Menurut teori dinamis Schumpeter, keuntungan pengusaha dapat tercipta karena penemuan dari para pengusaha itu sendiri. Penemuan yang dimaksud adalah penemuan cara-cara baru dan kombinasi baru dalam proses produksinya, artinya untuk memperoleh laba yang maksimal pengusaha harus lebih kreatif dan inovatif dalam menjalankan usahanya. Hal ini sejalan dengan penelitian Hadiati (2014) yang menjelaskan bahwa pengusaha harus mempunyai kreativitas yang tinggi agar dapat meningkatkan pengembangan usaha yang dimilikinya.

Dengan kata lain, pengusaha harus mempunyai sikap mental yang positif. Sikap mental positif yang dimiliki oleh wirausaha dalam mengelola dan menjalankan usahanya dengan suatu motif yang mendasarinya kemudian akan membentuk suatu perilaku yang mendorong wirausaha untuk mengembangkan usahanya menjadi wirausaha yang sukses dan berhasil sesuai dengan keinginannya.

Jika seorang wirausaha mempunyai sikap mental yang positif dalam mengelola usahanya, maka motif yang mendasarinya akan membentuk suatu perilaku yang mendorong wirausaha tersebut untuk terus maju dan meraih keuntungan yang diinginkan. Dengan demikian dapat disimpulkan bahwa, seorang pengusaha yang mempunyai sikap kewirausahaan, maka pengusaha tersebut dapat mengembangkan usahanya dengan peningkatan keuntungan usahanya.

Hal ini juga sesuai dengan Teori Tindakan Beralasan dari Fishbein dan Ajzen (2010), dimana sikap positif dapat mengarahkan kepada sebuah perilaku atau tindakan yang positif juga. Hal tersebut juga berlaku ketika seseorang berwirausaha. Semakin positif sikap seseorang terhadap suatu objek, maka atas respon dari sikapnya tersebut akan memunculkan niat atau dorongan individu terhadap kemampuannya untuk melakukan suatu perbuatan atau memunculkan suatu perilaku tertentu yang kemudian diaplikasikan dalam suatu tindakan yang positif. Dengan demikian, dapat dikatakan bahwa sikap kewirausahaan dapat mempengaruhi perkembangan usaha melalui suatu tindakan yang positif sebagai respon dari sikap kewirausahaannya. 
Hat tersebut senada dengan pernyataan Octavia (2015) dalam penelitiannya, bahwa sikap kewirausahaan memberikan pengaruh yang signifikan terhadap Keberhasilan Usaha. Keberhasilan usaha ini dapat berwujud peningkatan penghasilan maupun keberhasilan dalam pengelolaan usahanya. Dewi (2016) dalam penelitiannya juga menambahkan bahwa sikap kewirausahaan berpengaruh positif terhadap kemampuan mengelola usaha. Sehingga dapat dikatakan bahwa jika sikap kewirausahaan yang dimiliki seseorang semakin baik berupa rasa percaya diri, berani mengambil risiko, memiliki sikap kepemimpinan, dan orientasi ke masa depan, maka kemampuan mengelola usaha akan menjadi lebih baik pula.

Berdasarkan pemaparan di atas, dapat disimpulkan bahwa sikap kewirausahaan berpengaruh positif terhadap perkembangan usaha. Ketika seorang pengusaha mempunyai sikap kewirausahaan yang positif, maka keuntungan atau laba yang diperoleh pengusaha tersebut bertambah dan perkembangan usahanya meningkat. Sebaliknya, ketika seseorang tidak mempunyai sikap kewirausahaan maka keuntungan atau laba yang diperoleh pengusaha tersebut tetap atau berkurang dan perkembangan usahanya kurang berkembang.

\section{KESIMPULAN}

Berdasarkan hasil penelitian dan pembahasan yang telah dikemukakan pada hasil dan pembahasan dapat ditarik kesimpulan: 1) Gambaran mengenai perkembangan usaha terkait laba pengusaha batik di sentra kerajinan batik kota Tasikmalaya sebagian besar masih tergolong memperoleh laba yang rendah yaitu sebanyak 24 orang $(77 \%)$ dari 31 pengusaha. Laba yang diperoleh pengusaha dari hasil produksi akan digunakan untuk mengembangkan perusahaan, yaitu dengan menginvestasikan kembali laba tersebut dalam bentuk pabrik dan peralatan baru, digunakan untuk membeli perusahaan lain, atau digunakan sebagai investasi keuangan oleh perusahaan. Namun melihat perolehan laba pengusaha batik di sentra kerajinan batik kota Tasikmalaya ini yang masih tergolong rendah, perkembangan usaha industri batik ini masih kurang berkembang. Sedangkan umum sikap kewirausahaan yang dimiliki para pengusaha batik di sentra kerajinan batik kota Tasikmalaya masih tergolong rendah, hal tersebut terlihat dari jawaban responden dan perhitungan terkait indikator-indikator sikap kewirausahaan yang masih tergolong ke dalam kategori rendah. Rendahnya sikap kewirausahaan yang dimiliki pengusaha batik disebabkan karena mereka tidak mendapatkan pendidikan dan pengetahuan yang cukup mengenai cara berwirausaha yang baik; 2) Sikap kewirausahaan berpengaruh secara positif dan signifikan terhadap perkembangan usaha. Hal tersebut terlihat dari nilai R2 sebesar 0,74. Nilai R Square (R2) menunjukkan bahwa besarnya pengaruh variable sikap kewirausahaan terhadap variabel perkembangan usaha adalah sebesar 0,741 atau 
sebesar $74,1 \%$. Artinya bahwa $74,1 \%$ perubahan laba pengusaha batik di sentra kerajinan batik kota Tasikmalaya dapat ditentukan atau dijelaskan oleh variabel sikap kewirausahaan, sedangkan sisanya $25,9 \%$ dipengaruhi oleh faktor-faktor lain Hal tersebut juga berarti semakin tinggi sikap kewirausahaan yang dimiliki oleh pengusaha maka dapat meningkatkan laba yang diperoleh pengusaha tersebut sehingga perkembangan usahanya juga meningkat. Ketika seorang pengusaha mempunyai sikap kewirausahaan yang positif, maka keuntungan yang diperoleh akan meningkat sehingga perkembangan usahanya akan meningkat pula, sebaliknya ketika seorang pengusaha tidak mempunyai sikap kewirausahaan yang positif, maka keuntungan yang diperoleh tida akan meningkat dan perkembangan usahanya tidak akan meningkat pula.

\section{DAFTAR PUSTAKA}

Dewi, Ni Luh Anggita (2016). Pengaruh Sikap Kewirausahaan terhadap Kemampuan Mengelola Usaha pada Peserta Program Mahasiswa Wirausaha (PMW) UNDIKSHA Tahun 2015. Jurnal Program Studi Pendidikan Ekonomi (JPPE), 7(2).2016

Fadiati, Ari \& Dedi Purwana. (2011) Menjadi Wirausaha Sukses. Bandung: CV Rosdakarya.

Fishbein, M., \& Ajzen, I. (2010). Predicting and changing behavior: The reasoned action approach. New York: Taylor \& Francis.

Hadiyati, Ernani. (2014) Kreativitas dan Inovasi Berpengaruh Terhadap Kewirausahaan Usaha Kecil. Jurnal Administrasi Bisnis, 313-322.

Octavia, Jayanti. (2015). Pengaruh Sikap Kewirausahaan dan Kompetensi Wirausaha terhadap Keberhasilan Usaha (Survey pada Produsen Sepatu Cibaduyut Kota Bandung). Jurnal Riset Akuntansi VII(1), 41-59

Sukirno, Sadono. (2002). Pengantar Teori Mikroekonomi. Jakarta: Rajawali Pers. Suryana. (2006). Kewirausahaan. Jakarta: Salemba Empat. 